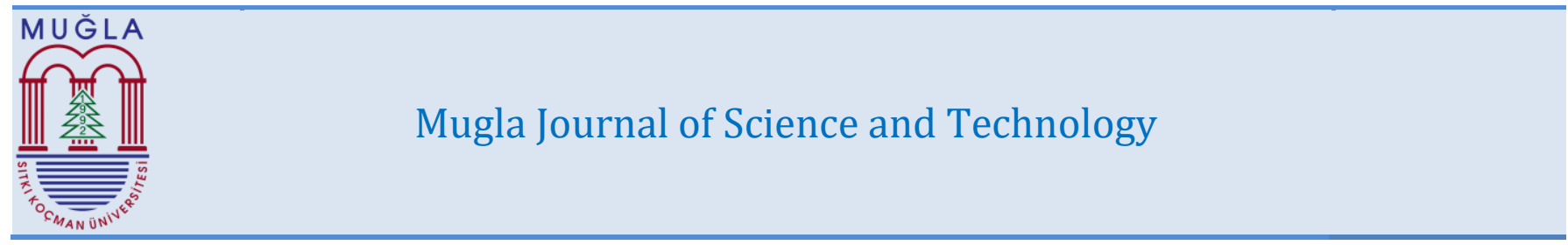

\title{
AN EXPERIMENTAL STUDY ON THE MINERALOGICAL CHARACTERIZATION OF THE SARIBEYLİ, KAOLIN DEPOSIT (ÇANAKKALE, NW TURKEY)
}

\author{
Merve Gülcan ${ }^{*}$, Yağmur Özcan ${ }^{1}$, Ceren Küçükuysal ${ }^{1}$ \\ ${ }^{1}$ Geological Engineering Department, Faculty of Engineering, Muğla Sıtkı Koçman University, Kötekli, 48000, Muğla/Turkey \\ mervegulcn.93@gmail.com*, yagmurozcan092@gmail.com, cerenkucukuysal@mu.edu.tr
}

Received: 28.02.2017, Accepted: 09.05.2017

doi: $10.22531 /$ muglajsci.295333

*Corresponding author

\begin{abstract}
This study, we focus on the mineralogical characterization of Sarıbeyli kaolin deposit by different instruments. Sarıbeyli kaolin deposit situated in Canakkale, NW Turkey has been explored and used as raw materials in various industries for many years. This experimental work defines clay and nonclay minerals of the deposit, by Methylene Blue Test (MB), X-ray Diffraction (XRD), Scanning Electron Microscope-Energy Dispersive Spectrometry (SEMEDS) and Differential Thermal Analysis-Thermogravimetry (DTA-TG). MB test results reveal the presence of a clay mineral having low specific surface area and low cation exchange capacity. This is confirmed by XRD with basal eflections of kaolinite at $7.14 \AA$ and $3.57 \AA$. The non-clay minerals of alunite and quartz were determined by their prominent peaks at $5.69 \AA$ and $3.34 \AA$, respectively. SEM-EDS analysis reveals that the kaolinite is well-crystallized and authigenically formed showing stacks of platelets with abundant Al and Si. The thermal behaviours of the Saribeyli kaolin deposit was tested by DTA$T G$. The first endothermic reaction at $537.24^{\circ} \mathrm{C}$ shows the dehydroxilation of kaolinite and the second one presents $\alpha$ to $\beta$ quartz transformation at $666.12^{\circ} \mathrm{C}$. All the findings of this experimental work clearly suggest that the presence of kaolinite, quartz and alunite as hydrothermal alteration products. Keywords: Mineralogy, Micromorphology, Hydrothermal Alteration, Methylene Blue test, X-Ray Diffraction, Sarıbeyli kaolin.
\end{abstract}

\section{SARIBEYLİ KAOLEN YATAKLARININ MİNERALOJİK KARAKTERIZZASYONU ÜZERİNE DENEYSEL BİR ÇALIŞMA (ÇANAKKALE KB TÜRKIYE)}

Öz

Bu çalışmada, Sarıbeyli kaoleninin farklı yöntemler ile mineralojik karakterizasyonu amaçlanmıştır. Türkiye'nin kuzeybatısında, Çanakkale'de yer alan Sarıbeyli kaoleni yıllar boyunca araștırılmıș ve halen farklı birçok endüstriye hammadde olmaktadır. Bu deneysel çalıșma, metilen mavisi deneyi (MB), $x$ ışını kırınımı (XRD), taramalı elektron mikroskobisi-enerji saçılım spektrometresi (SEM-EDS) ve diferansiyel termal analiz- termogravimetre (DTA-TG) analizleri ile Sarıbeyli kaoleninin kil ve kil dışı mineral içeriğini tanımlamaktadır. MB testinin sonuçlarına göre baskın kil mineralinin, düşük katyon değişim kapasitesine sahip olan kaolinit olduğu düşünülmüsstür. Bu sonuç, XRD ile elde edilen14 Å and $3.57 \AA$ yansımaları ile teyit edilmiștir. Kil dışı minerallerden olan alunit ve kuvars ise sırasıly 5.69 Å and 3.34 Å yansımalarını vermiştir. SEM-EDS analizlerinde kaolinitin iyi kristallenmiş ve otojenik olduğu, aynı zamanda Al ve Si'ca zengin, tabaka yığınları morfolojisinde olduğu gözlenmiștir. Sarıbeyli kaoleninin termal davranıșları DTA-TG ile test edilmiştir. Illk endotermik reaksiyon $537.24^{\circ} \mathrm{C}$ derecede gözlenmiş olup ve kaolinitin yapısının dehidroksilayonunu belirtmektedir. Ikinci endotermik reaksiyon ise $\alpha$-kuvarsın $\beta$-kuvarsa dönüșümünün $666.12^{\circ} \mathrm{C}$ derecede olduğunu göstermiştir. Bu deneysel çallşmadan elde edilen tüm bulgular, Sarıbeyli kaoleninin hidrotermal alterasyon ürünü olan kaolinit, kuvars ve alunit içerdiğini net bir şekilde göstermiștir.

Anahtar Kelimeler: Mineraloji, Mikromorfoloji, Hidrotermal Alterasyon, Metilen Mavisi Testi, X-Işını Kırınımı, Sarıbeyli kaoleni.

\section{Introduction}

Clay minerals are hydrous layer silicates belonging to the family of phyllosilicates, and form from aqueous solutions interacting with other pre-existing, mostly silicate species by dissolutionrecrystallization processes [16].Thus, the origin of clay minerals is related to water-rock interactions [16]. They can be formed in different geological environments as weathering zones, deserts, glaciers, rivers, lacustrine, estauries, deltas, marine, aeolian and hydrothermal [11].

Hydrothermal environments are highly possible places to have transformation of rocks into clay mineral or related paragenesis: kaolinite, sericite, montmorillonite, chlorite, pyrophyllite, alunite, serpentine, etc. [6] Hydrothermal kaolin deposits are the result of the transformation of crystalline rocks, metamorphic or volcanic, under the influence of deep hydrothermal solutions [11]. The recent studies [6],[7],[8],[9] proved that in Turkey, Çanakkale is one of the most susceptible areas to have hydrothermal deposits where kaolinite is accepted to be one of the key minerals to develop the knowledge on the classification of the alterations. The hinterland of Saribeyli village is the widely studied in terms of its economical resources, therefore, has been a subject of many geological studies [6] , [9]. An early works generally have characterized the mineralogy of the deposit by commonly single instrumental methods and have gone for the origins of the alteration minerals [8], [9]. It is only an experimental work to better characterize the mineralogical composition of the Sarıbeyli kaolin deposit which was donated by ESAN ECZACIBAȘI. In this present study, the subject is to evaluate the mineralogical composition of the Sarıbeyli kaolin deposit by multi-instrumental analysis.

\section{Materials and Methods}

The Sarıbeyli kaolin deposit is well known and widely used in the ceramic, plastic and paper industry. Multi-instrumental techniques as Methylene Blue Test (MB), X-ray Diffraction (XRD), Scanning Electron Microscope-Energy Dispersive 
Spectrometry (SEM-EDS) and Differential Thermal AnalysisThermogravimetry (DTA-TG) were used in this study to characterize the mineralogical composition of the Sarıbeyli kaolin deposit.

\subsection{Methylene Blue Test}

This method is a very quick test to understand the possible clay minerals in the composition of the studied sample. This test was carried out in the Clay Mineralogy Laboratory of the Geological Engineering Department at Muğla Sitkı Koçman University. Firstly Methylene Blue (MB) solution was prepared according to the method of [10]. 3gr methylene blue is weighed and mixed with $300 \mathrm{cc}$ distilled water by magnetic stirrer for 3 minutes. At the same time, the Saribeyli kaolin sample was powdered by agate pastle and mortar and then sieved from $63 \mu \mathrm{m}$ sieve (\#200). Following up, 7.5 gr sample was weighed, mixed with $50 \mathrm{cc}$ distilled water by magnetic stirrer.

Methylene blue solution was placed in a brute that was fixed at vertical position over the beaker containing clay-water mixture. 1cc methylene blue was added to the sample-water mixture and mixed continuously by magnetic stirrer for 1 minute. Immediately after, a droplet was taken from the MB added sample-water mixture with the help of a glass pipette and placed on a filter paper. The colour change and geometry of the adsorbed methylene blue within droplet was monitored till the white halo around the dark blue droplet became light blue colored that means the subsitution of cations between the methylene blue and clay minerals were completed (Fig 1).

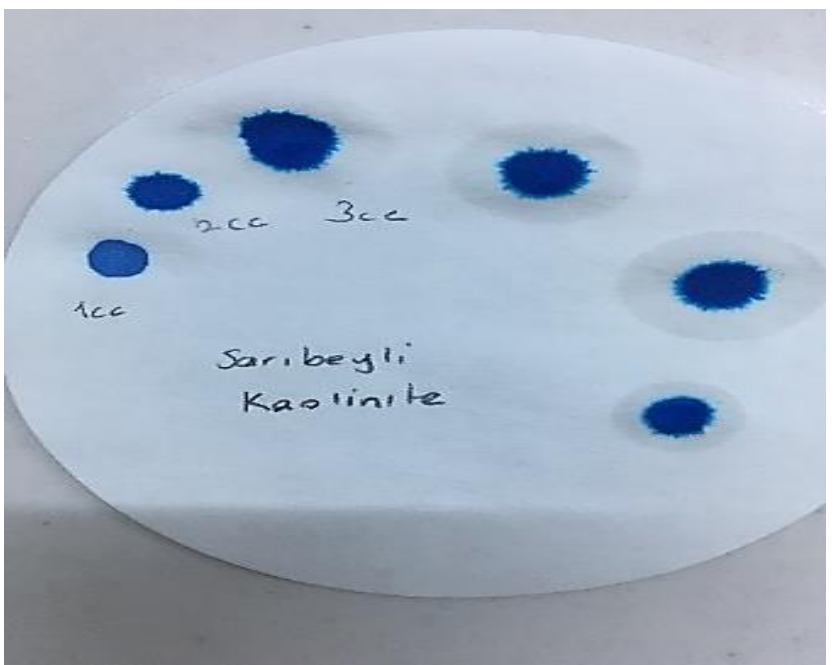

Figure 1. Light blue halo around dark blue droplet.

The amount of the MB solution creating the light blue halo around the current droplets were recorded to be used in the equations given below to calculate Cation Exchange Capacity (CEC) of the studied sample. The CEC of the samples was also calculated with the provided formula equation (1) [4].

$$
\text { (C. E. C. })=100 / f^{*} V c c^{*} N_{M B}=(m e q / 100 g r)
$$

where f stands for dry weight of clay sample (7.5 gr), Vcc is the amount of methylene blue diluted added to clay sample, $\mathrm{N}_{\mathrm{MB}}$ is the normality of the MB solution (standard $=0.028$ ).

\subsection{X-Ray Diffraction Analysis}

For X-ray diffraction analysis, the most important part was the sample preparation. Two different size fractions were used in this part of the work. The first was the bulk powder of the sample which was already prepared for the MB test. The second sample was prepared firstly by disaggregation and was placed in a $600 \mathrm{ml}$ beaker with distilled water. $3 \mathrm{gr}$ of Na-hexametaphosphate was added to avoid the flocculation. The laboratory temperature at the time of experiment was $22^{\circ} \mathrm{C}$ so according to Stoke's law, to separate $<2 \mu \mathrm{m}$ fraction, 22 hours and 11 minutes waited. After this time passed, the supernate was siphonned off to a depth of $8 \mathrm{~cm}$ by using a rubber hose into a $300 \mathrm{ml}$ beaker. This siphonning procedure from the settling beakers continued until the water in the beaker became clear after the settling time passed. When it was completed, the sludge in the settling beaker was the size-fraction of $>2 \mu \mathrm{m}$ and the siphonned slurry was $<2 \mu \mathrm{m}$.

The separated clay-size fraction was then placed into 6 centrifuge tubes. After balancing the tubes, they were placed into high speed centrifuge (Sigma 3-15L) for spin of approximately 10 minutes at $10,000 \mathrm{rpm}$. After the decanting supernatant liquid and homogenization of the clay paste, oriented clay mounts were prepared by smearing on glass slides (Fig 2). For this study, only air-dried slide was examined by XRD.

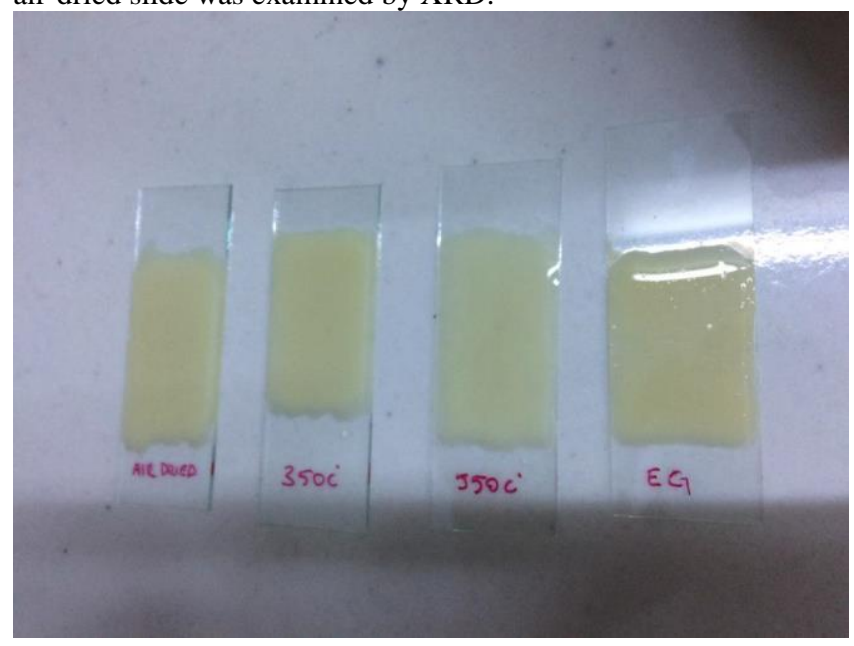

Figure 2. Glass slides prepared for XRD

X-Ray Diffraction analysis was carried at Research and Application Centre For Research Laboratories at Muğla Sitkı Koçman University. X-ray diffraction is the most common technique used to study the characteristics of crystalline structures and to determine the mineralogy of fine grained materials, especially clays. Comparing with the MB test, X-ray diffractometry is more attractive because of its speed and ease of performance, and because it requires only small amounts of material and is non-destructive, it has been widely used to perform semi-quantitative analyses of poly-mineralic mixtures [13].

Mineralogical composition of the sample was determined by Xray diffraction analysis, operating Rigaku Diffractometer equipped with a $\mathrm{Cu}$ tube at $40 \mathrm{Kv}$ voltage and $30 \mathrm{Ma}$ current. The diffactograms of the bulk powder and the clay-size oriented glass slide were plotted between $2^{\circ}-70^{\circ} 2 \theta$ and $2^{\circ}-42^{\circ} 2 \theta$ with a scanning rate of $1^{\circ} / \mathrm{min}$, respectively. Mineral identification was based on the combined methods of [3], [10], [14].

\subsection{Scaning Electron Microscope (SEM) Analysis}

All figures should be centered in the column, but if a figure is Scanning Electron Microscope Analysis was carried out at Research and Application Centre For Research Laboratories at Muğla Sıtkı Koçman University. The specimens were sputter coated with gold (Emitech K550X Sputter Coating Systems). All samples were examined under a scanning electron microscope (SEM) (Jeol JSM-7600F, Japan) at an accelerating voltage of 15 $\mathrm{kV}$. Elemental characterization of the samples was analyzed using the SEM equipped with Energy dispersive X-ray spectrometry (EDS) (Oxford Instruments). 


\subsection{Differential Thermal Analysis - Thermogravimetry (DTA-TG)}

Differential Thermal Analysis - Thermogravimetry analysis was performed by Perkin Elmer TGA 4000 in the Differential Thermal Analysis - Thermogravimetry ( DTA-TG) laboratory in the Chemistry Department at Muğla Sitkı Koçman University. The sample was powdered before the analysis. DTA-TG was used to analyse different thermal behaviours of the minerals as well as the mass loss with ncreasing heating rate from 36-780 ${ }^{\circ} \mathrm{C}$.

Table 1. Calculation of the Cation Exchange Capacity

\begin{tabular}{cccc}
\hline $\mathbf{c c}$ & $\mathbf{f}$ & $\mathbf{N}_{\mathbf{M b}}$ & (C.E.C)meq/100gr \\
\hline $2 \mathrm{cc}$ & $7.5 \mathrm{gr}$ & $0.028 \mathrm{gr}$ & $0.74 \mathrm{meq}$ \\
$3 \mathrm{cc}$ & & & $1.12 \mathrm{meq}$ \\
\hline
\end{tabular}

\section{Results and Discussion}

\subsection{Methylene Blue Analysis}

The filter paper clearly showed that the Saribeyli kaolin sample was absorbed the MB solution by adding $2 \mathrm{cc}$ at minimum and $3 \mathrm{cc}$ at maximum values (Fig 3). Therefore, they were accepted to be $V_{c c}$ values to be used in the calculations. After all the procedures were completed, the data obtained from the analysis were used in the calculation of CEC values with respect to the given formula of (1). The CEC results were shown in Table 1 .

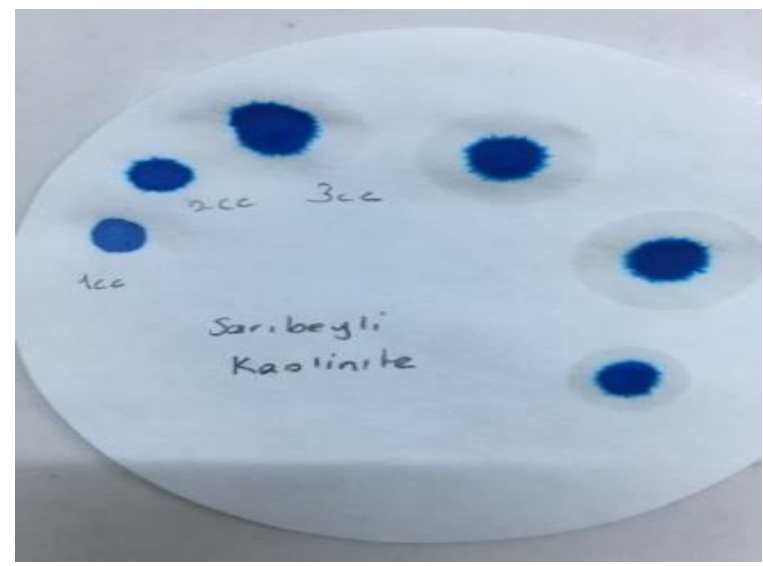

Figure 3.Minimum and maximum values of the MB-clay mixture on the filter paper.

Cation exchange capacities of clay minerals [5], [1] are given in Table 2. Comparison of the CEC values of $0,74 \mathrm{meq} / 100 \mathrm{gr}$ and $1.12 \mathrm{meq} / 100 \mathrm{gr}$ with the known reference values, our sample was detected to be in kaolinite group. Hyperlinks can be used in the paper. Hyperlinks can be utilized as the links (documents, audio, multi-media etc.) that provide more information about the related topic. Font type of an hyperlink must be same as that of the main text but it should be underlined.

Table 2. Cation exchange capacity of clay minerals.

\begin{tabular}{lll}
\hline \multirow{2}{*}{ Minerals } & \multicolumn{2}{l}{ Cation Exchange Capacity (meq/100 gr) } \\
& Drever (1982) & Bain et al. (1994) \\
\hline Smectite & $80-150$ & $60-150$ \\
Vermiculite & $120-200$ & $100-150$ \\
Illite & $10-40$ & $10-40$ \\
Kaolinite & $1-10$ & $3-15$ \\
Chlorite & $<10$ & $10-40$ \\
\hline
\end{tabular}

\subsection{X-ray Diffraction Analysis}

Bulk X-ray diffractogram shows the presence of kaolinite with its dominant peaks at $7.14 \AA$ (12.3920), $4.36 \AA$, (20.36 20) 3.57 $\AA(24.872 \theta), 2.53 \AA(36.062 \theta)$. Alunite was also observed with its major reflection at $5.69 \AA$ (15 $2 \theta), 4.96 \AA$ (17.81 2ө) $2.98 \AA($ $29.882 \theta), 2.88 \AA(30.942 \theta), 2.29 \AA(39.342 \theta)$. The associated quartz mineral was documented with the observation of $3.34 \AA$ (26 2 Ө), $4.25 \AA$ ( $20.852 \theta$ ) $2.28 \AA$ (39.52 20) peaks (Fig 4).

The air-dried glass slide of the clay size fraction was $x$-rayed and the kaolinite with its dominant peaks at $7.17 \AA(12.392 \theta)$ ,3.58 $\AA$ (24.87 20) were recognized together with alunite (5.31 $\AA ̊ ̊$ and $4.97 \AA$ ) and quartz (3.34 ̊̊ and 2.28 Å) (Fig 5).

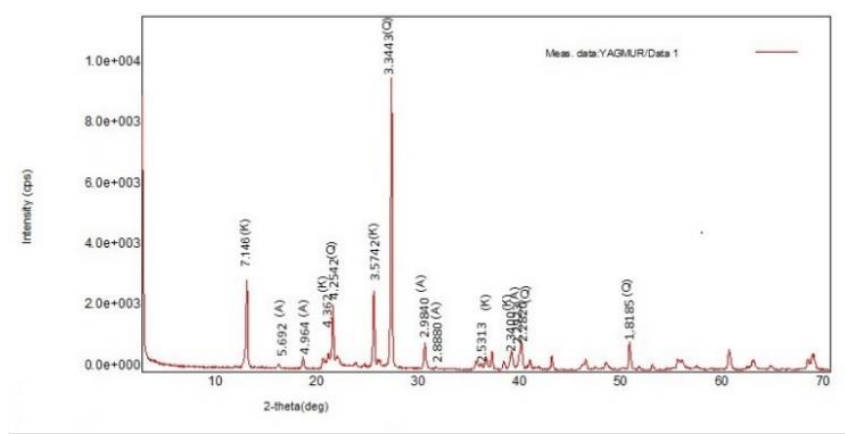

Figure 4. X-Ray diffractogram of the bulk sample

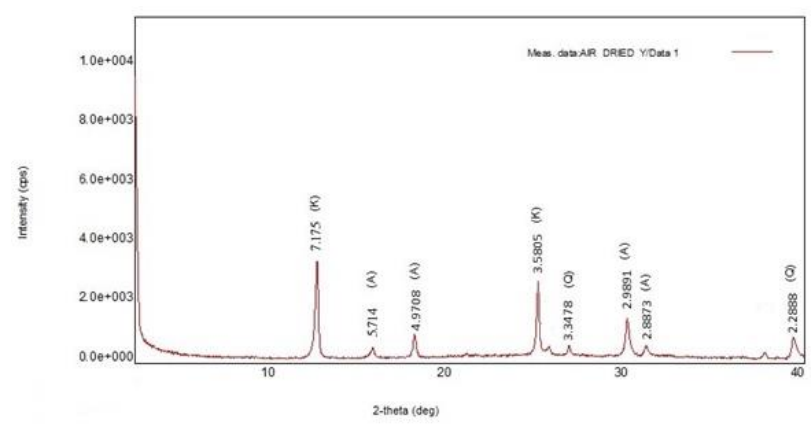

Figure 5. X-ray diffractogram of clay size fraction.

\subsection{Scanning Electron Microscope Analysis}

The studied Sarıbeyli kaolinite sample was also investigated by SEM-EDS. The presence of kaolinite, quartz and alunite were all revealed in the SEM images. The formation of authigenic kaolinite was inferred with its well crystallized overgrowth showing face to face stacks of pseudohexagonal plates (Fig 6a, b). The in situ formed alunite crystals were also realized between kaolinite stacks (Fig 6c). The hexagonal crystal habit of quartz was clearly observed in (Fig 6d). 


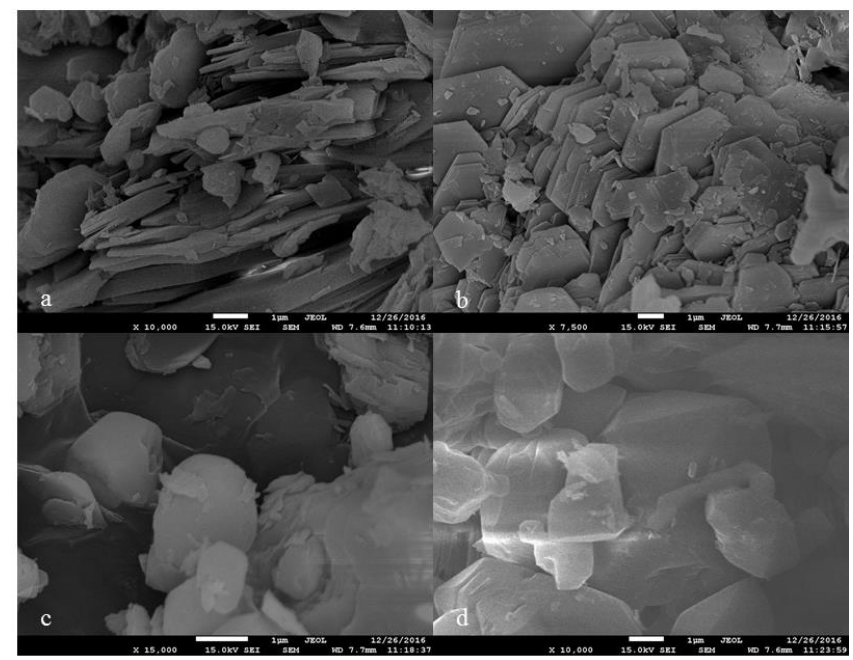

Figure 6. SEM images of the minerals from Sarıbeyli kaolin sample: $(a, b)$ well-crystallized authigenic kaolinite occurring face to face stacks of pseudohexagonal plates; (c) alunite crystal surrounded by kaolinite plates; (d) euhedral crystals of authigenic quartz overgrowth.

The kaolinite presence was also confirmed by EDS the kaolinite presence was also confirmed by EDS analysis which shows equal Si (14.78\%) and Al (14.52\%) contents together with high 0 (66.12\%) (Fig 7). The EDS on a single quartz grain shows high Si (24.99\%) and very high 0 (68.47 \%) (Fig 8).

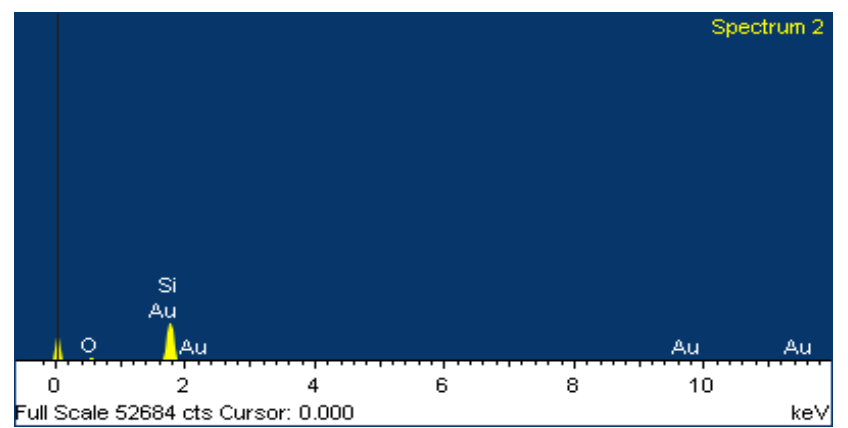

Figure 7. EDS analysis of authigenic kaolinite

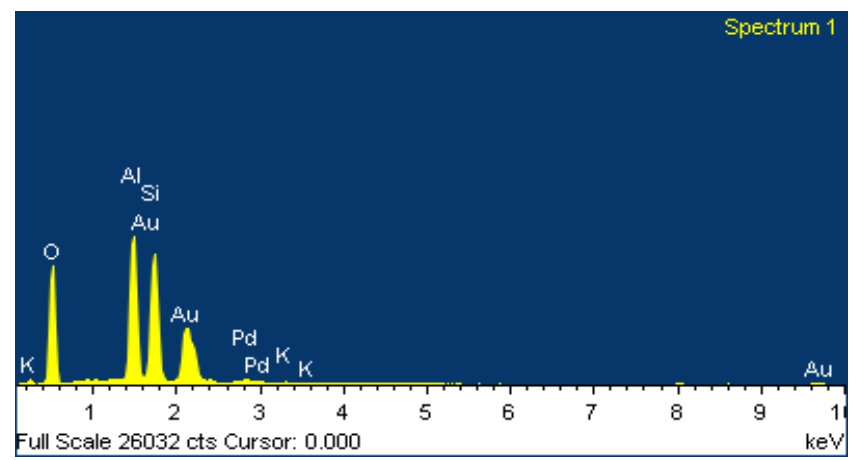

Figure 8. EDS analysis of authigenic quartz

\subsection{Differential Thermal Analysis - Thermogravimetry (DTA-TG)}

The first endothermic peak was observed at $53.47^{\circ} \mathrm{C}$. This is related with the non-structural water within the sample. The second endothermic peak at $117.48^{\circ} \mathrm{C}$ is because of the loss of structural water.

The broad endothermic peak at $537.24^{\circ} \mathrm{C}$ was due to dehydroxilation of kaolinite a slightly sharp peak at $666.12^{\circ} \mathrm{C}$ was attributed to the $\alpha$ to $\beta$ quartz transformation. DTA curve clearly shows the presence of kaolinite. TG curved shows that the mass loss was approximately $2 \mathrm{mg}$ (Fig 9).

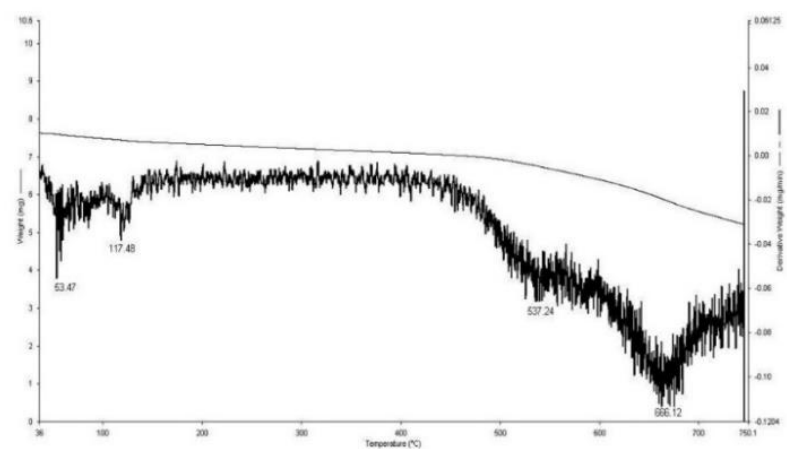

Figure 9. DTA-TG curve showing the thermal behaviours and mass loss of the sample with respect to the temperature increase

\section{Conclusion}

As an experimental work on the Sarıbeyli kaolin deposit, the findings from methylene blue test, $x$-ray diffraction, scanning electron microscope-energy dispersive spectrometry and differential thermal analysis-thermogravimetry are all compatible with each other supporting the presence of authigenic kaolinite, quartz and alunite as the products of hydrothermal alteration.

\section{Acknowledgement}

We would like thank ESAN ECZACIBAȘI for donating the Sarıbeyli kaolin sample to the Clay Mineralogy Laboratory in Geological Engineering Department at Mugla Sitkı Koçman University. The valuable help of Assist. Prof. Dr. Elif VARGÜN in DTA-TG analysis are greatly appreciated.

\section{References}

[1] Bain, D. C. Smith, B.F. L., Wilson, M. J., Ed. Clay mineralogy :Spectroscopy and Chemical Determinative Methods, Champman and Hall New York, USA.300p 1994.

[2] Chamley, H., . Clay Sedimentology, Springer, Verlang Berlin Heildeberg Newyork, 626p. 1989.

[3] Chen, P.Y., Table of key lines in X-ray powder diffraction patterns of minerals in clays and associated rocks. Department of Natural Resources, Geological Survey Occasional Paper 21. Bloomington, Indiana, USA. 1977.

[4] Çokca, E., Birand, A.A., Determination of cation Exchange capacity of clayley soils by the methylne blue test Geotechnical Testing journal ,GTJODJ 16(4),518-524. 1993b.

[5] Drever, J. I. The Geochemistry of Natural Waters. PrenticeHall, Englewood Cliffs, N.J., 388 p. 1982.

[6] Ece, Ö. I., Schroeder, P. A., Smilley, M. J., \& Wampler., J. M. Acid-sulphate hydrothermal alteration of andesitic tuffs and genesis of halloysite and alunite deposits in the Biga Peninsula, Turkey. GeoScienceWorld, 2008.

[7] Ercan, H. Ü., Ece, Ö. I., \& Karacık, Z. Differentiating styles of alteration within kaolin-alunite hydrothermal deposits of Çanakkale, NW Turkey. Clays and clay minerals 64 (3):245$274 p, 2010$.

[8] ] Ercan, H. Ü., Ece, Ö. I., \& Karacık, Z. .Mineralogical and Geochemical Characterization of Çan Volcanics and Releated Kaolin Deposits, Çanakkale, Turkey. International 
Multidisciplinary Scientific GeoConference:Surveying Geology \& mining Ecology Management; Sofia 1: 121-128, 2013,

[9] Ercan, H. Ü., Ece, Ö. I., Schroeder, P. A., \& Karacik, Z. Differentiating styles of alteration within kaolin-alunite hydrothermal deposits of Çanakkale, NW Turkey. GeoScienceWorld, 2016.

[10] Jones, F.O., New fast accurate test measures bentonite in drilling mud, Oil Gas J., June, pp.76- 78. 1964.

[11] Millot,G., Geology of Clays. Weathering, Sedimentology, Geochemistry. Springer, Paris. 443p. 1970.

[12] Moore, D.M. \& Reynolds, J.R. X-ray Diffraction and the Identification and Analysis of Clay Minerals. Oxford University Press, Oxford 1989.

[13] Poppe, L.J., Paskevich, V.F., Hathaway, J.C., and Blackwood, D.S., A Laboratory Manual for X-Ray Powder Diffraction. U. S. Geological Survey Open-File Report 01-041. 2002.

[14] Thorez, J. Practical Identification of Clay Minerals. Lelotte, Dison, Belgium $42,1976$.

[15] Üveges, J.B., Horváth, Z., Michéli, E., Mindszenty, A., Németh, T., Reconstructing Quaternary pedogenesis in a paleosol sequence in Hungary. Quaternary International, 106107, 61-71 2003.

[16] Velde, B. \& Meunier, A. The Origin of Clay Minerals in Soils and Weathered Rocks. xii + 406 pp. Berlin, Heidelberg, New York: Springer-Verlag 2008 